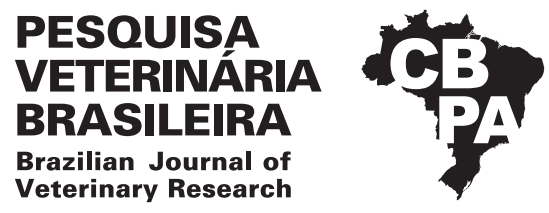

Pesq. Vet. Bras. 38(12):2213-2216, dezembro 2018 DOI: 10.1590/1678-5150-PVB-5982

Original Article

Animais de Produção/Livestock Diseases

ISSN 0100-736X (Print)

ISSN 1678-5150 (Online)

\title{
Rhinosporidiosis in horses ${ }^{1}$
}

\author{
Fernando F. Argenta ${ }^{2}$, Lauren S. Mello², Andreia Vielmo², Saulo P. Pavarini², \\ David Driemeier ${ }^{2}$ and Luciana Sonne ${ }^{2 *}$
}

\begin{abstract}
Argenta F.F., Mello L.S., Vielmo A., Pavarini S.P., Driemeier D. \& Sonne L. 2018. Rhinosporidiosis in horses. Pesquisa Veterinária Brasileira 38(12):2213-2216. Setor de Patologia Veterinária, Departamento de Patologia Clínica Veterinária, Faculdade de Veterinária, Universidade Federal do Rio Grande do Sul, Av. Bento Gonçalves 9090, prédio 42505, Porto Alegre, RS 91540-000, Brazil. E-mail: lusonne@yahoo.com.br

Rhinosporidiosis is a disease caused by Rhinosporidium seeberi, an aquatic protist of the class Mesomycetozoa. It primarily affects the nasal mucosa and transmission is associated with contaminated water contact. This report describes seven cases of rhinosporidiosis in horses in Rio Grande do Sul covering the period of 13 years. The disease predominantly affected Crioulo and thoroughbred horses. No apparent gender predisposition occurs, and age ranged from two to 25 years, with a median of 10 years. The gross aspects were characterized by unilateral $(85.7 \%, 6 / 7)$ or bilateral $(14.3 \%, 1 / 7)$ polyps. These were soft to friable, whitish to pink, cauliflower-like, with an irregular, sometimes ulcerated surface, measuring 2.5 to $6.0 \mathrm{~cm}$ in diameter. There was a severe inflammatory infiltrate of the submucosa was observed, associated with moderate proliferation of the epithelium, and numerous rounded structures were identified compatible with sporangia of $R$. seeberi. Rhinosporidiosis should be included in the differential diagnosis of other conditions affecting the respiratory tract of horses, and it is important to perform histopathology for diagnosis.
\end{abstract}

INDEX TERMS: Horses, rhinosporidiosis, rhinitis, Rhinosporidium seeberi, parasitoses.

RESUMO.- [Rinosporidiose em equinos.] A rinosporidiose é uma doença causada por Rhinosporidium seeberi, protista aquático da classe Mesomycetozoa. Acomete principalmente a mucosa nasal e a transmissão está associada ao contato com água contaminada. Este trabalho descreve sete casos de rinosporidiose em equinos no Rio Grande do Sul em um período de 13 anos. A doença afetou predominantemente cavalos de raça, como Crioulo e Puro Sangue Inglês, sem predisposição sexual evidente e a idade variou de dois a 25 anos, com a mediana de 10 anos. Macroscopicamente foram caracterizadas por pólipos unilaterais $(85,7 \% ; 6 / 7)$ ou bilaterais $(14,3 \% ; 1 / 7)$. Os pólipos eram macios a friáveis, esbranquiçados a róseos, com aspecto de couve flor e com superfície irregular, por vezes ulcerada, medindo 2,5 a $6,0 \mathrm{~cm}$ de diâmetro. Havia infiltrado inflamatório piogranulomatoso acentuado na submucosa associado à moderada proliferação do epitélio e numerosas estruturas arredondadas compatíveis com esporângios de $R$. seeberi. A rinosporidiose deve ser

\footnotetext{
${ }^{1}$ Received on July 26, 2018.

Accepted for publication on August 9, 2018

${ }^{2}$ Setor de Patologia Veterinária, Faculdade de Veterinária, Universidade Federal do Rio Grande do Sul (UFRGS), Av. Bento Gonçalves 9090, prédio 42505, Porto Alegre, RS 91540-000, Brazil. *Corresponding author: lusonne@yahoo.com.br
}

incluída no diagnóstico diferencial de outras patologias que acometem o trato respiratório de equinos, sendo importante a realização da histopatologia para diagnóstico.

TERMOS DE INDEXAÇÃO: Cavalos, rinosporidiose, rinite, Rhinosporidium seeberi, parasitoses.

\section{INTRODUCTION}

Rhinosporidiosis is a disease that affects several animal species and humans (Caswell \& Williams 2016) and is caused by Rhinosporidium seeberi, classified as aquatic protist belonging to the class Mesomycetozoa (Santos \& Guedes 2016, López \& Martinson 2017). The disease occurs predominantly in tropical and subtropical regions (Caswell \& Williams 2016), mainly affecting the nasal mucosa and transmission is associated with contact with contaminated water. Mucosal wounds favor the entrance of the agent which induces a focal granulomatous lesion (Kennedy et al. 1995, Leeming et al. 2007).

The affected animals may be asymptomatic or present clinical signs characterized by nasal secretion, sneezing, epistaxis, breathing noise (Easley et al. 1986, Burgess et al. 2012, Caswell \& Williams 2016) and obstruction of the nasal cavity occasionally (Brenseke \& Saunders 2010). The diagnosis of 
rhinosporidiosis is based on observation through histological examination (Santos \& Guedes 2016) and the indicated treatment is surgical excision (Arseculeratne \& Mendoza 2005).

This study describes seven cases of rhinosporidiosis in horses in the state of Rio Grande do Sul, with emphasis on epidemiological and pathological findings.

\section{MATERIALS AND METHODS}

The records of histopathological examinations carried out from January 2004 to December 2016 in the Department of Veterinary Pathology of the Federal University of Rio Grande do Sul (SPV-UFRGS) were reviewed for cases of rhinosporidiosis in horses. Samples from the nasal cavity of horses from the metropolitan region of Porto Alegre and Northeastern of Rio Grande do Sul, Brazil, were fixed in 10\% formalin. Epidemiological data such as age, sex and breed, as well as the date of examination, anatomical location and clinical signs were obtained from histopathological examinations. Paraffin blocks were obtained from the SPV-UFRGS files and new histological sections were stained with hematoxylin and eosin (HE) and periodic acid-Schiff (PAS).

\section{RESULTS}

From January 2004 to December 2016, the SPV-UFRGS received 832 equine biopsies, seven of which were diagnosed as rhinosporidiosis, corresponding to $0.8 \%$ of all cases. When only samples from the nasal cavity of horses were analyzed, the frequency was $31.8 \%(7 / 22)$. Crioulo and Thoroughbred were the affected breeds, with $71.4 \%$ (5/7) and 14.3\% (1/7), respectively. An affected horse had no defined breed $(14.3 \%$, 1/7). Of the total, $57.1 \%$ (4/7) were females and $42.9 \%$ (3/7) males. Age ranged from 2 to 25 years, with median of 10 years. Clinical history was reported in four cases and sero-sanguinolent nasal secretion (3/4), epistaxis (1/4) and respiratory distress $(1 / 4)$ were the clinical signs described.

Macroscopically, the lesions were characterized by polypoid mucosal thickening in the nasal cavity. The polyps were found as a solitary unilateral lesion $(85.7 \%, 6 / 7)$ or as multiples bilateral formations $(14.3 \%, 1 / 7)$. They were soft to friable, whitish to rosy, cauliflower-like aspect and irregular surface, sometimes ulcerated, measuring 2.5 to $6.0 \mathrm{~cm}$ in diameter (Fig.1A).
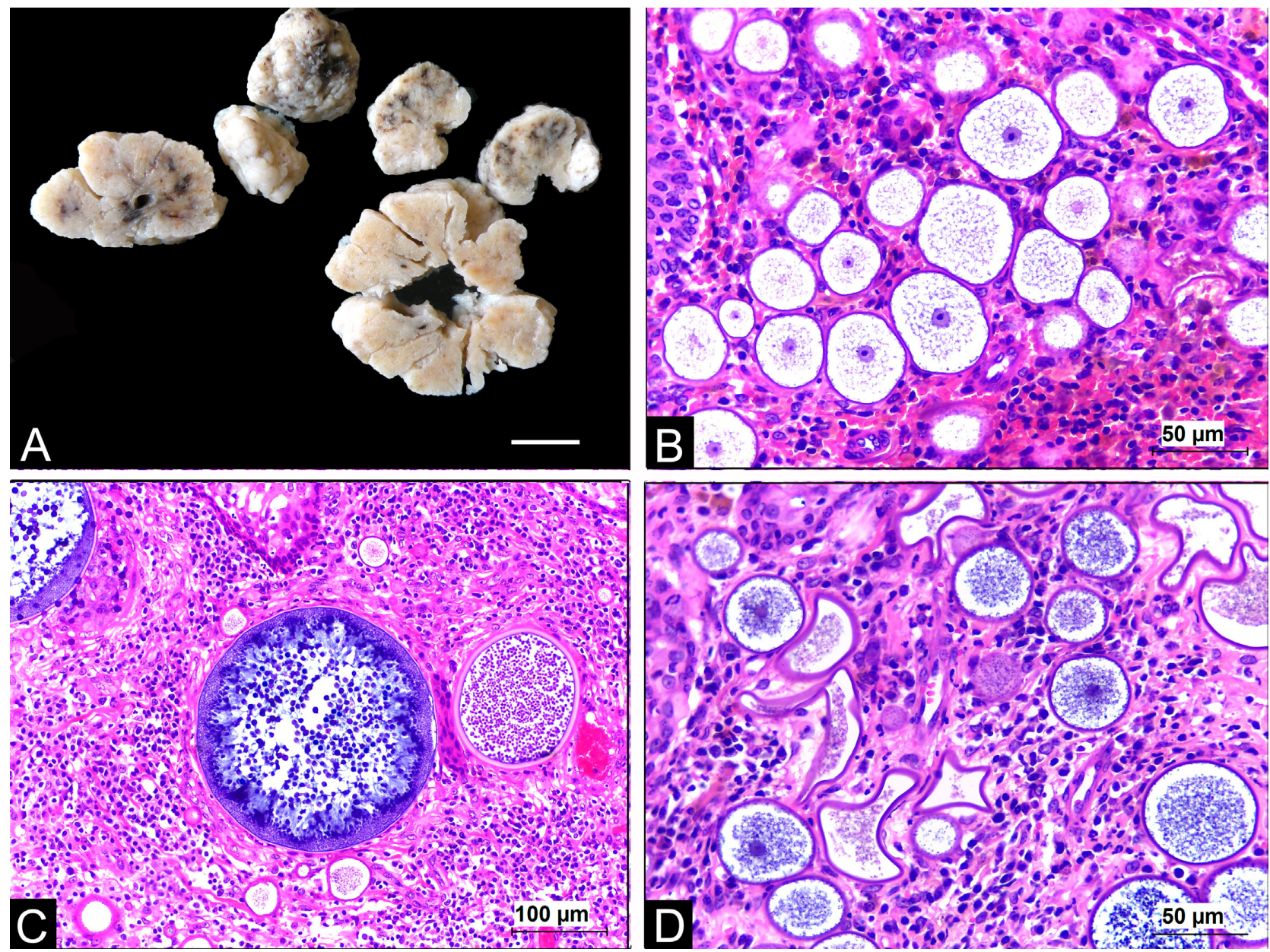

Fig.1. Rhinosporidiosis in horses. (A) Multiple samples of white, cauliflower-like polypoid nodule. Specimens fixed in $10 \%$ formalin. (B) Numerous rounded structures of different sizes, the largest measuring $55 \mu \mathrm{m}$ in diameter, unilamellar wall, central nucleus, surrounded by basophilic granular material, compatible with young Rhinosporidium seeberi sporangia. Inflammatory infiltrate of lymphocytes and plasma cells is also observed. $\mathrm{HE}$, bar $=50 \mu \mathrm{m}$. (C) Mature Rhinosporidium seeberi sporangia, the largest measuring $250 \mu \mathrm{m}$ in diameter and the smallest $120 \mu \mathrm{m}$, with multiple young (periphery) and mature endospores (central) inside. HE, bar $=100 \mu \mathrm{m}$. (D) Several empty and collapsed sporangia and young sporangia and inflammatory infiltrates of lymphocytes, plasm cells and macrophages. $\mathrm{HE}, \mathrm{bar}=50 \mu \mathrm{m}$. 
Histopathological examination revealed a polypoid structures lined by moderate epithelial proliferation associated with a marked inflammatory infiltrate of macrophages, lymphocytes and plasm cells, and occasional neutrophils. Numerous rounded structures of variable size (20 to $500 \mu \mathrm{m}$ in diameter) were identified along with inflammation and in different stages of development, compatible with Rhinosporidium seeberi sporangia. Young sporangia presented unilamellar wall, central nucleus, surrounded by basophilic granular material measuring from 10 to $100 \mu \mathrm{m}$ in diameter (Fig.1B). The unilamellar wall of young sporangia was visualized mainly by PAS staining. The mature ones presented bilamellar wall, with multiple endospores, measuring from 100 to $500 \mu \mathrm{m}$ (Fig.1C). Immature endospores were in the periphery of the sporangium and mature ones in the central region, which is spherical, with numerous eosinophilic bodies inside. There were occasional ruptured sporangia releasing endospores through the apical pore in the epithelium, and also multifocally in the submucosa. In addition, multiple empty and collapsed sporangia were visualized (Fig.1D). In the mucosa, multiple areas of ulceration, with deposition of amorphous fibrillar material, necrotic debris and bacterial myriads were also observed.

\section{DISCUSSION}

The seven cases were diagnosed as rhinosporidiosis based on the characteristic histological features of the disease. The diagnosis of the disease is based on the visualization of Rhinosporidium seeberi sporangia in histology, associated with respiratory clinical signs when present (Pereira \& Meireles 2007), since the culture of the microorganism was not performed, as it cannot be isolated in artificial mediums (Jungerman \& Shwartzman 1972).

In the present study, the rhinosporidiosis frequency was $0.8 \%$ of the total histopathological samples, and $38.1 \%$ when samples from the nasal cavity were analyzed. In a study of equine diseases, the frequency was $0.3 \%$ (Marcolongo-Pereira et al. 2014). In a study of tumor lesions of the nasal cavity of horses, rhinosporidiosis was the second major disease (Trotte et al. 2008), representing $27.3 \%$ of the total lesions. The low rhinosporidiosis frequency may be related to the non-reporting of cases and because not all surgically excised nasal lesions are submitted to histopathological examination (França et al. 1997).

Rhinosporidiosis affects both sexes (Londero et al. 1977), and in relation to the age group, the disease presents great variation (Londero et al. 1977, Nollet et al. 2008, Trotte et al. 2008, Burgess et al. 2012, Santos et al. 2014, Bernardo et al. 2016), as identified in the present study. The disease predominantly affected Crioulo horses, and this may be related to the higher prevalence of this breed in the state of Rio Grande do Sul (Silva \& Farias 2017).

In horses, the lesion is predominantly located in the nasal mucosa and rarely in the larynx region (Nollet et al. 2008, Burgess et al. 2012, Santos et al. 2014). This high frequency of involvement of the nasal mucosa can be explained by contamination with pathogen spores in soil and water, thus the inhalation of dust and/or contact of the nasal mucosa with contaminated water inoculated via traumatic lesions would be the possible means of transmission (França et al. 1997, Caswell \& Williams 2016). Therefore, one should suspect the existence of a source of infection in the place where horses are kept and of environmental characteristics, which favor the perpetuation and development of $R$. seeberi, such as flooded areas (Tiwari et al. 2015).

Macroscopic and microscopic rhinosporidiosis lesions observed in this study are similar to those described by other authors (Londero et al. 1977, Caswell \& Williams 2016, López $\&$ Martinson 2017). The morphological characteristics of the different stages of $R$. seeberi found in equines are compatible with those described in literature (Chandler et al. 1980, Leeming et al. 2007, Burgess et al. 2012, Santos et al. 2014). The different stages of $R$. seeberi are easily observed in sections stained by HE; however, histochemical techniques such as PAS can be used to highlight sporangia walls (Easley et al. 1986).

The diseases of the nasal cavity of horses present similar clinical signs, mainly characterized by nasal secretion, epistaxis and respiratory distress (Nickels 1993). Differential diagnoses include rhinitis caused by Aspergillus spp., Coccidioides immitis (Caswell \& Williams 2016), Cryptococcus neoformans, Histoplasma spp., Pythium insidiosum (Trotte et al. 2008) and Emmonsia parva or E. crescens (Caswell \& Williams 2016). Other conditions affecting the nasal cavity of horses, such as congenital nasal cysts, inflammatory polyps, nasal amyloidosis, neoplasms, nasal granuloma caused by hypersensitivity and ethmoidal progressive hematoma (Pereira \& Meireles 2007) should also be considered. Definitive diagnosis depends on the histopathological examination of nodular lesions in the nasal cavity of horses with the identification of the different stages of R. seeberi (Berrocal \& Lopez 2007).

\section{CONCLUSIONS}

Rhinosporidiosis presented low frequency in horses in Rio Grande do Sul; however, when nasal cavity samples were analyzed, it was the most frequently diagnosed disease.

The disease affected predominantly Crioulo horses, with no predisposition for sex and with great age group variation.

This disease should be included in the differential diagnosis of other pathologies affecting the upper respiratory tract of horses. Histopathological examination is decisive in the diagnosis.

\section{REFERENCES}

Arseculeratne S.N. \& Mendoza L. 2005. Rhinosporidiosis, p.436-475. In: Merz W.G. \& Hay R.J. (Eds), Topley and Wilson's Microbiology and Microbial Infections. 10th ed. Hodder Arnold, London.

Bernardo F.D., Pazinato F.M., Alves C.E.F., Bueno V.C., Franciscato C. \& Elias F 2016. Rinosporidiose nasal em equino no Sul do Rio Grande do Sul, Brasil. Revta Bras. Med. Vet. 38(2):175-180.

Berrocal A. \& Lopez A. 2007. Nasal rhinosporidiosis in a mule. Can. Vet. J 48(3):305-306. <PMid:17436910>

Brenseke B.M. \& Saunders G.K. 2010. Concurrent nasal adenocarcinoma and rhinosporidiosis in a cat. J. Vet. Diagn. Invest. 22(1):155-157. <http:// dx.doi.org/10.1177/104063871002200135><PMid:20093709>

Burgess H.J., Lockerbie B.P., Czerwinski S. \& Scott M. 2012. Equine laryngeal rhinosporidiosis in western Canada. J. Vet. Diagn. Invest. 24(4):777-780. <http://dx.doi.org/10.1177/1040638712445773><PMid:22604769>

Caswell J. \& Williams K. 2016. Respiratory system, p.579-586. In: Maxie M.G. (Ed.), Jubb, Kennedy and Palmer's Pathology of Domestic Animals. Vol.2. 6th ed. Elsevier Saunders, Philadelphia. 
Chandler F.W., Kaplan W. \& Ajello L. 1980. Rhinosporidiosis, p.109-111. In: Chandler F.W., Kaplan W. \& Ajello L.A. (Eds.), Colour Atlas and Textbook of the Histopathology of Mycotic Diseases. Wolfe, Lochem.

Easley J.R., Meuten D.J., Levy M.G., Dykstra M.J., Breitschwerdt E.B., Holzinger E.A. \& Cattley R.C. 1986. Nasal rhinosporidiosis in the dog. Vet. Pathol. 23(1):50-56. <http://dx.doi.org/10.1177/030098588602300108> <PMid:2418574>

França G.V., Gomes C.C., Sakano E., Altemani A. \& Shimizu L.T. 1997. Rinosporidiose nasal na infância. J. Pediatr. 70:299-301.

Jungerman P.F. \& Shwartzman R.M. 1972. Rhinosporidiosis, p.40-47. In: Jungerman P.F. \& Schwartzman R.M. (Eds), Veterinary Medical Mycology. Lea and Febiger, Philadelphia.

Kennedy F.A., Buggage R.R. \& Ajello L. 1995. Rhinosporidiosis: a description of an unprecedented outbreak in captive swans (Cygnus spp.) and a proposal for revision of the ontogenic nomenclature of Rhinosporidium seeberi. J. Med. Vet. Mycol.33(3):157-165. <http://dx.doi.org/10.1080/02681219580000341> <PMid:7666295>

Leeming G., Smith K.C., Bestbier M.E., Barrelet A. \& Kipar A. 2007. Equine rhinosporidiosis in United Kingdom. Emerg. Infect. Dis. 13(9):1377-1379. <http://dx.doi.org/10.3201/eid1309.070532> <PMid:18252114>

Londero A.T., Santos M.N. \& Freitas C.J.B. 1977. Animal rhinosporidiosis in Brazil. Report of three additional cases. Mycopathologia 60(3):171-173. <http://dx.doi.org/10.1007/BF00448411> <PMid:559253>

López A. \& Martinson S.A. 2017. Respiratoy system, mediastinum, and pleurae, p.490. In: Zachary J.F. (Ed.), Pathologic Basis of Veterinary Disease. 6th ed. Elsevier, Missouri. <http://dx.doi.org/10.1016/B978-0-323-357753.00009-6>.

Marcolongo-Pereira C., Estima-Silva P., Soares M.P., Sallis E.S.V., Grecco F.B., Raffi M.B., Fernandes C.G. \& Schild A.L. 2014. Doenças de equinos na região
Sul do Rio Grande do Sul. Pesq. Vet. Bras. 34(3):205-210. <http://dx.doi. org/10.1590/S0100-736X2014000300002>

Nickels F.A. 1993. Diseases of the nasal cavity. Vet. Clin. N. Am., Equine Pract. 9(1):111-121. <http://dx.doi.org/10.1016/S0749-0739(17)30418-2> $<$ PMid:8472195>

Nollet H., Vercauteren G., Martens A., Vanschandevijl K., Schauvliege S., Gasthuys F., Ducatelle R. \& Deprez P. 2008. Laryngeal rhinosporidiosis in a Belgian Warmblood horse. Zoo Publ. Health 55:274-278. <http://dx.doi. $\operatorname{org} / 10.1111 / \mathrm{j} .1863-2378.2008 .01112 . \mathrm{x}>$

Pereira D.B. \& Meireles M.C.A. 2007. Doenças causadas por fungos e oomycetos, p.467-469. In: Riet-Correa F., Schild A.L., Lemos R.A.A. \& Borges J.R.J. (Eds), Doenças de Ruminantes e Equídeos. Vol.1. $3^{a}$ ed. Pallotti, Santa Maria.

Santos R.L. \& Guedes R.M.C. 2016. Sistema respiratório, p.7. In: Santos R.L. \& Alessi A.C. (Eds), Patologia Veterinária. 2nd ed. Roca, Rio de Janeiro.

Santos A.C., Nogueira C.E.W., Vieira P.S., Araujo L.O., Amaral L.A., Pazinato F.M., Santos F.C.C. \& Curcio B.R. 2014. Rinosporidiose nasal e laringeana em equino. Acta Scient. Vet. 42(62):1-5.

Silva B.P. \& Farias C.V.S. 2017. Cadeia de criação e comercialização do cavalo Crioulo no Rio Grande do Sul. Revta Teoria e Evidência Econômica 23(48):1-29.

Tiwari R., Karthik K., Dhama K., Shabbir M.Z. \& Khurana S.K. 2015. Rhinosporidiosis: a riddled disease of man and animals. Adv. Anim. Vet. Sci. 3(2s):54-63. <http://dx.doi.org/10.14737/journal.aavs/2015/3.2s.54.63>

Trotte M.N.S., Santos I.B., Miranda L.H.M., Amorim A.R., Borges J.R.J. \& Menezes R.C. 2008. Histopatologia de lesões tumoriformes presentes na cavidade nasal de equídeos do Brasil. Ciência Rural 38(9):2535-2539. <http:// dx.doi.org/10.1590/S0103-84782008000900019> 